\title{
Program PECS (Picture Exchange Communication System) untuk Meningkatkan Kemampuan Berbicara Terstruktur pada Anak Autis
}

\author{
Restu Vistasari ${ }^{1} \mathcal{E}$ Bhina Patria ${ }^{2}$ \\ Fakultas Psikologi Universitas Gadjah Mada
}

\begin{abstract}
Most of children with autism have difficulty with their communication skill. One of the specific problems is about to combine words into structured sentences when they tried to speak. The purpose of this research was to examine the efficacy of PECS in improving of structured language skills to children with autism. Participants of this research consisted of two children who have been diagnosed with autism. Dependent variable of this study was structured language skill in speaking and independent variable of the study was The PECS Program which had been modified in some phases. The method that was used in this study is single-case research with A-B-A design. Behavior checklist was used as the instrument for this research, also data of this research were analyzed by visual inspection. The result of visual inspection analysis showed that there were some improvements in grammatical language skills of the participants throughout the PECS program.
\end{abstract}

Keywords : autism; PECS; structured language skill

Abstrak. Sebagian besar anak autis mengalami kesulitan berkomunikasi, terutama dalam mengombinasikan kata menjadi kalimat utuh yang terstruktur dalam sebuah pembicaraan. Tujuan dari penelitian ini adalah untuk menguji efektivitas program PECS dalam meningkatkan kemampuan berbicara terstruktur pada anak Autis. Partisipan dalam penelitian ini adalah dua orang anak dengan diagnosis autisme. Variabel tergantung dalam penelitian ini adalah kemampuan berbicara terstruktur, sedangkan variabel bebasnya adalah penerapan program PECS yang sudah dimodifikasi pada beberapa fasenya. Metode penelitian yang digunakan adalah metode eksperimen single case dengan desain A-B-A. Pengukuran di dalam penelitian ini menggunakan instrumen behavior checklist dengan analisis data visual inspection. Hasil penelitian menunjukkan bahwa adanya peningkatan dalam kemampuan berbicara terstruktur pada kedua partisipan melalui program PECS yang telah dilakukan.

Kata kunci : autism; kemampuan berbicara terstruktur; PECS

Temuan mengenai fenomena prevalensi anak autis dilaporkan meningkat dari tahun ke tahun. Data yang dirilis oleh WHO (Labola, 2017) mengungkapkan jika sampai pada tahun 2016, negara Indonesia mengalami peningkatan yang signifikan terhadap jumlah penyandang autis yaitu dari 1 per-1000 penduduk menjadi 8 per-1000 penduduk. Berdasarkan definisi yang dijelaskan dalam DSM V (American Psychiatric Association [APA], 2013), autisme adalah gangguan perkembangan pervasif yang ditandai dengan adanya pola rutinitas

\footnotetext{
1 Korespondensi mengenai isi artikel ini dapat dilakukan melalui restuvistasari@gmail.com

2 atau melalui patria@ugm.ac.id
} 
yang kaku dan bersifat repetitif, serta gangguan yang memiliki kelemahan dalam hal menjalin interaksi komunikasi sosial dengan orang lain (Kerig, Ludlow \& Wenar, 2002) baik secara verbal maupun non verbal (Parritz \& Troy, 2007), seperti adanya keterlambatan atau kemunduran dalam hal berbicara (Thunberg, 2013). Sejalan dengan hal ini, Frith (2003) bahkan mengungkapkan jika sebagian besar anak autis mengalami permasalahan dalam hal keterlambatan berbahasa jika dibandingkan anak normal yang lainnya.

Dalam penggunaannya, bahasa memiliki lima aspek utama yaitu fonologi, morfologi, sintaksis, semantis dan juga pragmatis (Santrock, 2010). Pada individu autis yang memiliki kemampuan verbal satu kata, permasalahan yang sering dihadapi adalah pada aspek sintaksis atau terkait dengan penyusunan kalimat, (Parritz \& Troy, 2011). Hal ini dikarenakan beberapa dari anak autis cenderung babbling pada saat berbicara, menggunakan kata yang tidak tepat dalam konteks kalimat, atau bahkan mengulang beberapa kata dari lawan bicaranya (repetitive words/phrases). Bartolucci, Pierce, dan Streiner (1980) mengungkapkan bahwa anak dengan gangguan autisme cenderung akan menghilangkan morfem pada beberapa kata yang coba mereka katakan pada orang lain. Hal ini ditunjukkan dengan seringnya mereka menghilangkan beberapa kata awalan ataupun kata penghubung pada sebuah kalimat.

Salah satu program yang digunakan untuk menstimulasi komunikasi pada anak autis adalah program PECS (picture exchange comm unication system). Metode intervensi ini pertama kali dirancang oleh Andy Bondy dan Lory Frost (1994) untuk mengajarkan kemampuan komunikasi fungsional pada anak autis. Penggunaan media PECS ini didasarkan pada konsep visual support yang melibatkan penggunaan beberapa simbol gambar pada kartu yang menempel di papan komunikasi.

\section{Metode}

Desain yang digunakan pada penelitian ini merupakan metode eksperimen dengan bentuk single case (Shaugnessy, Zechmeister, \& Zechmeister, 2009). Metode eksperimen ini juga biasa disebut dengan "small-n research design". Lebih lanjut, Kazdin (2011) mengungkapkan jika metode single case seringkali digunakan dalam penelitian dengan pendekatan behavioral dengan tujuan untuk menganalisa perilaku. Intervensi program yang digunakan pada penelitian ini adalah Program PECS (picture exchange communication system). Modul yang telah dilakukan modifikasi dalam beberapa poin fasenya sudah melewati proses penilaian terhadap lima orang ahli (professional judges) dan memiliki koefisien validitas Aiken's V yang berkisar antara 0,75 hingga 0,90.

Pelaksanaan penelitian ini dimulai sejak bulan Oktober hingga Desember 2018. Terdapat 11 - 12 kali pertemuan dalam keempat fase yang dimiliki oleh program PECS ini. Instrumen penelitian yang digunakan untuk mengukur target perilaku adalah behavior checklist. Gambaran aktivitas program pada setiap fase dapat dilihat pada tabel 1 .

\section{Hasil}

Pada penelitian ini, pelaksanaan pengambilan data di fase baseline dan juga post-treatment dilakukan pada setting natural, seperti pada saat suasana proses pembelajaran di kelas yaitu ketika partisipan berinteraksi dengan guru ataupun teman-temannya. Berikut ini 
Tabel 1.

Kegiatan Intervensi Program PECS

\begin{tabular}{|c|c|}
\hline SUBMODUL & AKTIVITAS \\
\hline $\begin{array}{l}\text { Fase I } \\
\text { (Pengenalan Kartu } \\
\text { Bergambar) }\end{array}$ & $\begin{array}{l}\text { - Trainer memperlihatkan satu-persatu dari setiap klasifikasi kartu } \\
\text { bergambar (aspek subjek, predikat, objek) dihadapan partisipan. } \\
\text { - Trainer menanyakan mengenai setiap gambar yang ada di setiap } \\
\text { kartu pada partisipan. }\end{array}$ \\
\hline $\begin{array}{l}\text { Fase II } \\
\text { (Penyusunan Kalimat Pola } \\
\text { S-P) }\end{array}$ & $\begin{array}{l}\text { - Trainer menyebutkan contoh kalimat sederhana pada partisipan } \\
\text { yang terdiri dari aspek subjek dan predikat (SP). } \\
\text { - Trainer mengajak partisipan untuk menyusun kartu bergambar } \\
\text { dalam sebuah kalimat (SP) dan menempelkannya pada papan } \\
\text { strip yang telah disediakan. } \\
\text { - Trainer mengajak kembali partisipan untuk menyebutkan ulang } \\
\text { secara lisan mengenai deretan kartu bergambar yang telah } \\
\text { disusun pada papan strip kalimat sebelumnya. }\end{array}$ \\
\hline $\begin{array}{l}\text { Fase III } \\
\text { (Penyusunan Kalimat Pola } \\
\text { P-O) }\end{array}$ & $\begin{array}{l}\text { - Trainer menyebutkan contoh kalimat sederhana pada partisipan } \\
\text { yang terdiri dari aspek predikat dan objek (PO). } \\
\text { - Trainer mengajak partisipan untuk menyusun kartu bergambar } \\
\text { dalam sebuah kalimat (PO) dan menempelkannya pada papan } \\
\text { strip yang telah disediakan. } \\
\text { - Trainer mengajak partisipan kembali untuk menyebutkan ulang } \\
\text { secara lisan mengenai kartu bergambar yang telah disusun pada } \\
\text { papan strip kalimat sebelumnya. }\end{array}$ \\
\hline $\begin{array}{l}\text { Fase IV } \\
\text { (Penyusunan Kalimat Pola } \\
\text { S-P-O) }\end{array}$ & $\begin{array}{l}\text { - Trainer menyebutkan contoh kalimat sederhana pada partisipan } \\
\text { yang terdiri dari aspek subjek, predikat dan objek (S-P-O) } \\
\text { - Trainer mengajak partisipan untuk menyusun kalimat tersebut } \\
\text { dan menempelkannya pada papan strip melalui beberapa kartu } \\
\text { bergambar yang telah disediakan. } \\
\text { - Trainer mengajak partisipan untuk menyebutkan ulang secara } \\
\text { lisan susunan kartu bergambar yang telah diurutkan pada papan } \\
\text { strip kalimat. }\end{array}$ \\
\hline $\begin{array}{ll}\text { adalah hasil } & \text { dari } \\
\text { kemampuan } & \text { berbicara }\end{array}$ & intervensi program PECS. \\
\hline $\begin{array}{lll}\text { partisipan } & \text { GB } & \text { dan } F S \\
\text { sebelum dan } & \text { sesudah }\end{array}$ & $\begin{array}{l}\text { Partisipan } G B \\
\text { Pada penelitian ini, pelaksanaan pengam- }\end{array}$ \\
\hline
\end{tabular}

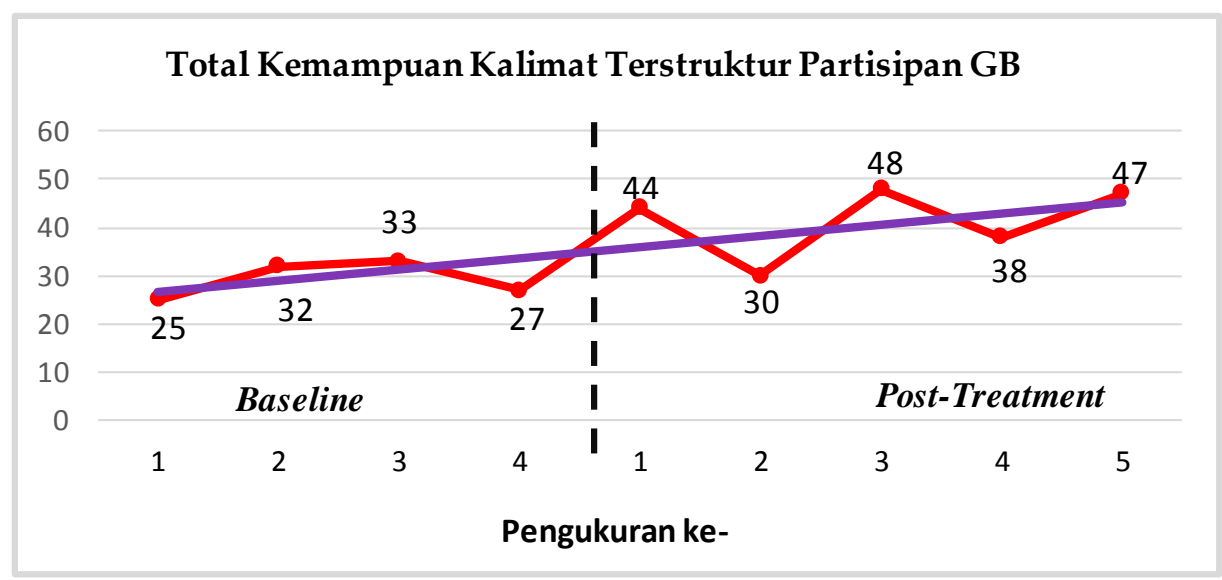

Grafik 1. Kemampuan berbicara terstruktur pada partisipan GB 
Tabel 2.

Analisis Visual Inspection Kemampuan Berbicara Terstruktur Partisipan GB

\begin{tabular}{|c|c|}
\hline Kondisi & Post-treatment \\
\hline Panjang kondisi & 4 \\
\hline Mean & 29.25 \\
\hline \multirow{2}{*}{\multicolumn{2}{|c|}{$\begin{array}{l}\text { Kecenderungan stabilitas } \\
\text { Kecenderungan arah } \\
\text { (free-hand) }\end{array}$}} \\
\hline & \\
\hline & (Meningkat) \\
\hline \multirow[t]{2}{*}{ Perubahan level dalam fase } & $27-25=2$ \\
\hline & $\begin{array}{ll}(+) \text { Meningkat } & (+) \text { Meningkat }\end{array}$ \\
\hline \multirow[t]{3}{*}{ Perubahan level antar fase } & Post Treatment - Baseline \\
\hline & $44-27=17$ \\
\hline & $(+)$ Meningkat \\
\hline bilan data di fase baseline dan juga post- & tabel 2 dan grafik 1 , maka dapat diketah \\
\hline treatment dilakukan pada setting natural, & jika kecenderungan arah (trend) $\mathrm{p}$ \\
\hline seperti pada saat suasana proses & grafik terlihat meningkat yaitu dari \\
\hline pembelajaran di kelas yaitu ketika & kondisi partisipan sebelum diberikannya \\
\hline partisipan berinteraksi dengan guru & intervensi (baseline) dengan kondisi \\
\hline ataupun teman-temannya. Gambar 1 & setelah dilakukannya intervensi (post- \\
\hline menunjukkan hasil dari perkembangan & treatment). Hal ini mengindikasikan jika \\
\hline kemampuan berbicara terstruktur & intervensi program PECS penyusunan \\
\hline partisipan GB sebelum dan sesudah & kalimat dapat meningkatkan \\
\hline diberikannya intervensi program PECS & kemampuan berbicara terstruktur pada \\
\hline penyusunan kalimat. & partisipan GB. Untuk \\
\hline Berdasarkan tabulasi data & kemampuan \\
\hline
\end{tabular}

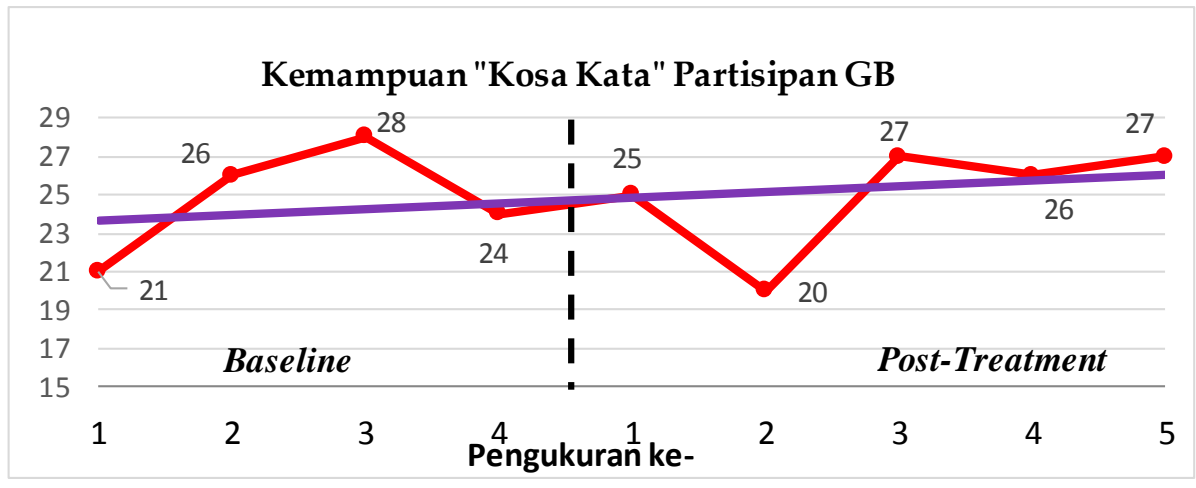

Grafik 2. Kemampuan kosa kata pada partisipan GB

Tabel 3.

Analisis Visual Inspection Kemampuan Kosa Kata Partisipan GB

\begin{tabular}{|c|c|c|}
\hline Kondisi & Baseline & Post-Treatment \\
\hline Panjang kondisi & 4 & 5 \\
\hline Mean & 24.75 & 25 \\
\hline \multicolumn{3}{|l|}{$\begin{array}{l}\text { Kecenderungan arah } \\
\text { (free-hand) }\end{array}$} \\
\hline & \multicolumn{2}{|c|}{ (Meningkat) } \\
\hline \multirow[t]{2}{*}{ Perubahan level dalam fase } & $24-21=3$ & $27-25=2$ \\
\hline & (+) Meningkat & $(+)$ Meningkat \\
\hline \multirow{3}{*}{ Perubahan level antar fase } & \multicolumn{2}{|c|}{ Post Treatment-Baseline } \\
\hline & \multicolumn{2}{|c|}{$25-24=1$} \\
\hline & \multicolumn{2}{|c|}{$(+)$ Meningkat } \\
\hline
\end{tabular}


masing-masing pola kalimat dapat dilihat pada grafik 2 .

Grafik 2 adalah gambaran perkembangan mengenai kemampuan kosa kata yang dimiliki oleh partisipan GB sebelum dan setelah dilakukannya intervensi.

Data pada tabel 3 dan grafik 2 menunjukkan adanya pola kecenderungan arah (trend) yang predikat (SP) pada partisipan GB. Kondisi pada saat post-treatment terlihat meningkat dibandingkan pada saat kondisi baseline yang terlihat pada tabel 4 . Di samping itu, skor perubahan level antar fase juga menunjukkan adanya peningkatan 8 poin. Hal ini menunjukkan bahwa program PECS penyusunan kalimat dapat memberikan dampak positif berupa meningkatkan

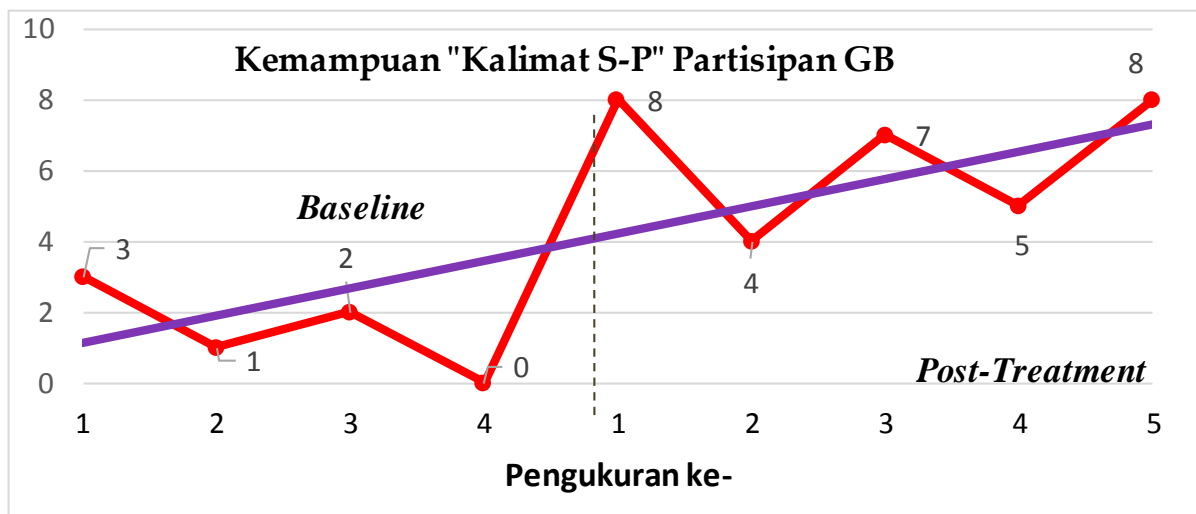

Grafik 3. Kemampuan kalimat subjek-predikat (SP) partisipan GB

Tabel 4.

Analisis Visual Inspection Kemampuan Kalimat Subjek-Predikat (SP) Partisipan GB

\begin{tabular}{lcc}
\multicolumn{1}{c}{ Kondisi } & Baseline & Post-Treatment \\
\hline Panjang kondisi & 4 & 5 \\
Mean & 1.5 & 6.4 \\
$\begin{array}{l}\text { Kecenderungan arah } \\
\text { free-hand) }\end{array}$ & \multicolumn{2}{c}{ (Meningkat) } \\
Perubahan level dalam fase & $0-3=-3$ & $8-8=0$
\end{tabular}

Perubahan level antar fase

$(-)$ Menurun $\quad(+)$ Menetap

Post Treatment - Baseline

$$
8-0=8
$$

$(+)$ Meningkat

mengalami peningkatan terhadap kemampuan kosa kata partisipan GB, jika dibandingkan antara kondisi sebelum dan setelah dilakukannya intervensi program PECS. Hal ini juga terlihat dari adanya perbedaan skor perubahan level antar fase yang mengalami peningkatan satu poin.

Kecenderungan arah trendline yang ada pada grafik 3 memperlihatkan adanya peningkatan kemampuan berbicara terstruktur pola subjek- kemampuan berbicara terstruktur pola subjek-predikat (SP) pada partisipan.

Grafik 4 memperlihatkan tentang perkembangan kemampuan penyusunan kalimat predikat-objek (PO) yang dimiliki oleh partisipan GB sebelum dan setelah dilakukannya intervensi.

Data pada tabel 5 dan grafik 4 menunjukkan jika adanya peningkatan kemampuan berbicara terstruktur dengan pola predikat-objek (PO) pada partisipan GB. Hal ini nampak dari ke- 


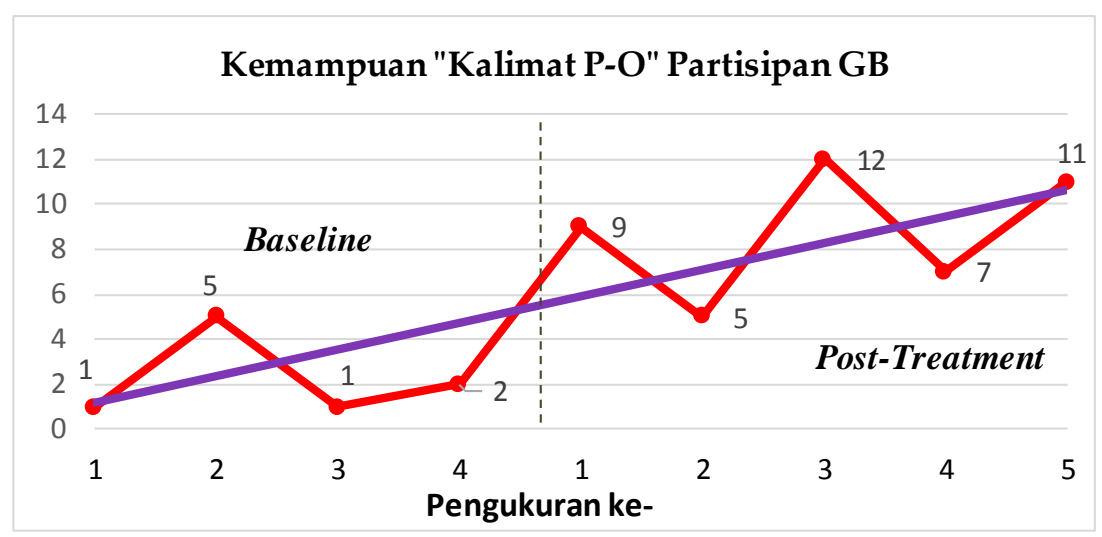

Grafik 4. Kemampuan kalimat predikat-objek (PO) partisipan GB

Tabel 5.

Analisis Visual Inspection Kemampuan Kalimat Predikat-Objek (PO) Partisipan GB

\begin{tabular}{lcc}
\hline \multicolumn{1}{c}{ Kondisi } & Baseline & Post-Treatment \\
\hline Panjang kondisi & 4 & 5 \\
Mean & 2.25 & 8.8 \\
$\begin{array}{l}\text { Kecenderungan arah } \\
\text { (free-hand) }\end{array}$ & \multicolumn{2}{c}{ (Meningkat) } \\
Perubahan level dalam fase & $2-1=2$ 11-9=2
\end{tabular}

Perubahan level antar fase

$(+)$ Meningkat (+) Meningkat

Post Treatment - Baseline

$$
9-2=7
$$

$(+)$ Meningkat

cenderungan arah (trend) pada grafik yang mengalami kenaikan pada kondisi post-treatment jika dibandingkan pada kondisi baseline. Selain itu, perubahan level antar fase juga menunjukkan adanya peningkatan sebesar 7 poin. Hal ini mengindikasikan jika intervensi program PECS penyusunan kalimat memberikan dampak peningkatan terhadap kemampuan berbicara terstruktur dengan pola kalimat predikatobjek (PO) pada partisipan GB.
Fase III pada program ini adalah mengenai meningkatkan kemampuan kalimat dengan pola SPO. Grafik 5 adalah hasil yang dimiliki oleh partisipan GB sebelum dan setelah dilakukannya intervensi.

Berdasarkan data di dalam tabel 6 dan juga grafik 5, dapat dilihat jika adanya peningkatan sebesar 1 poin di dalam perubahan level antar fase baseline dan juga post-treatment. Namun demikian, peningkatan yang terjadi ini

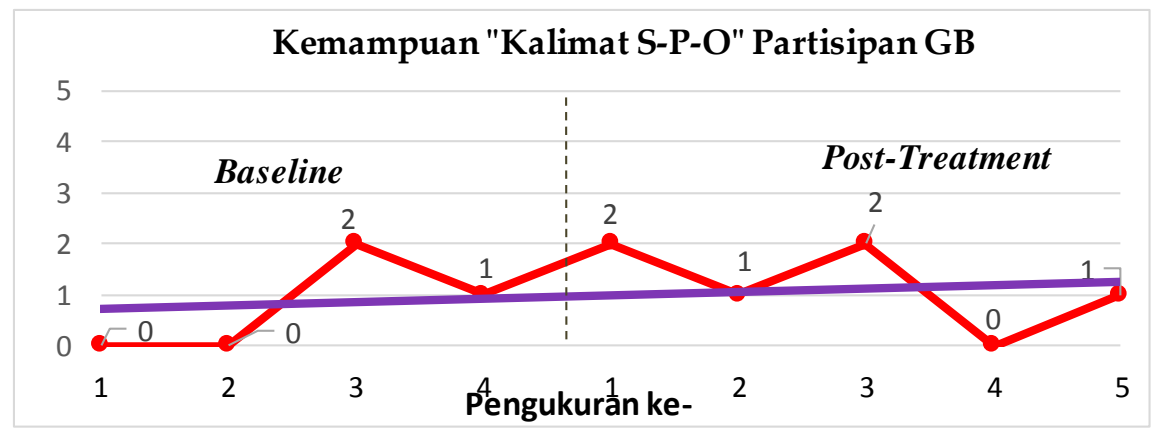

Grafik 5. Kemampuan kalimat subjek-predikat-objek (PO) partisipan GB 
Tabel 6.

Analisis Visual Inspection Kemampuan Kalimat Subjek-Predikat-Objek (SPO) Partisipan GB

\begin{tabular}{lcc}
\hline \multicolumn{1}{c}{ Kondisi } & Baseline & Post-Treatment \\
\hline Panjang kondisi & 4 & 5 \\
Mean & 0.75 & 1.2
\end{tabular}

Kecenderungan arah

(free-hand)

Perubahan level dalam fase

(cenderung konstan)

Perubahan level antar fase

$1-0=1$

(+) Meningkat

Post Treatment - Baseline

$$
1-0=1
$$

(+) Meningkat

cenderung tidak signifikan. Hal ini terlihat dari kecenderungan arah (trend) yang terjadi pada grafik lebih condong dalam membentuk garis yang konstan. Jika dibandingkan dengan efek yang terjadi pada kemampuan kalimat SP dan juga PO, maka untuk kemampuan SPO pada partisipan GB tidak mengalami efek peningkatan yang begitu signifikan.

\section{Partisipan FS}

Sama halnya dengan partisipan GB, proses pelaksanaan pengambilan data baseline dan juga post-treatment pada partisipan FS juga dilakukan pada setting yang natural. Proses pengambilan data baseline dilakukan selama tiga hari sedangkan pengambilan data untuk posttreatment dilakukan selama lima hari. Hal ini didasarkan pada nilai stabilitas pada data yang di ambil. Grafik 6 adalah data dan grafik dari perkembangan kemampuan berbicara terstruktur pada partisipan FS yang meliputi total dari kemampuan kosa kata, penggunaan kalimat SP (subjek-predikat), PO (predikat-objek) dan juga SPO (subjekpredikat-objek).

Berdasarkan grafik 6 dan tabel 7, dapat dilihat jika terjadi peningkatan pada kemampuan berbicara terstruktur kondisi baseline dengan kondisi pada saat post-treatment. Hal ini terlihat dari kecenderungan arah (trendline) yang menunjukkan garis meningkat setelah diberikannya intervensi. Pada perubahan level antar fase juga menunjukkan adanya kenaikan skor sebesar 20 poin pada peralihan fase baseline dan juga posttreatment. Hal ini mengindikasikan bahwa intervensi program PECS penyusunan kalimat dapat meningkatkan kemampuan berbicara terstruktur pada partisipan FS.

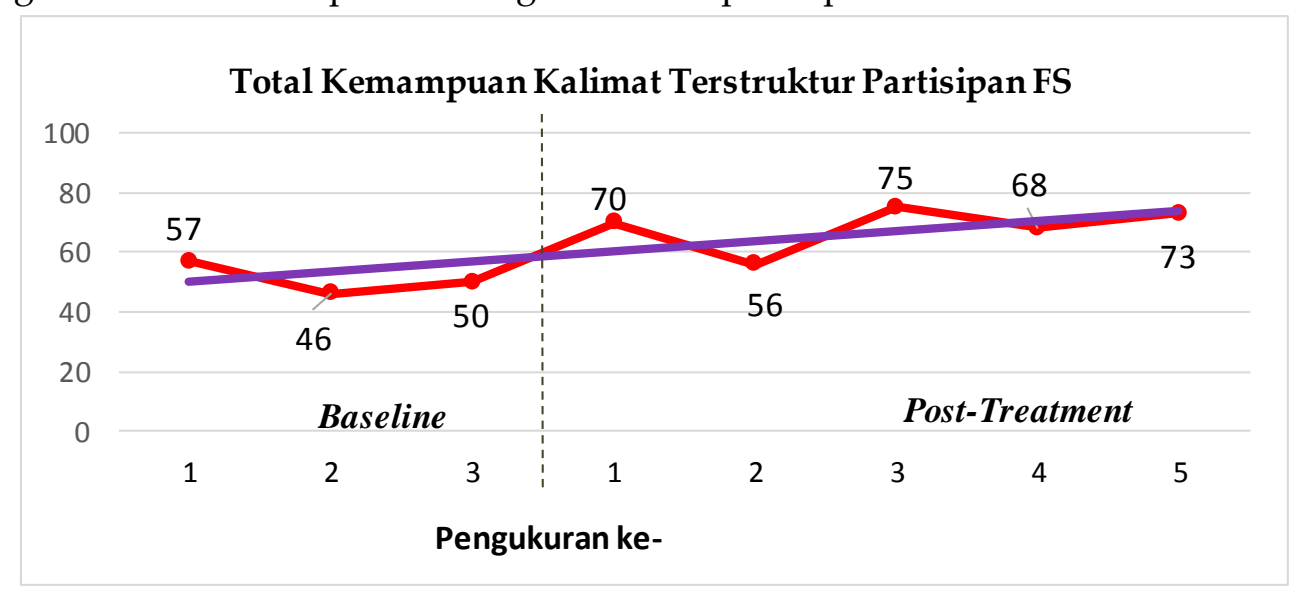

Grafik 6. Kemampuan berbicara terstruktur pada partisipan FS 
Tabel 7.

Analisis Visual Inspection Kemampuan Berbicara Terstruktur Partisipan FS

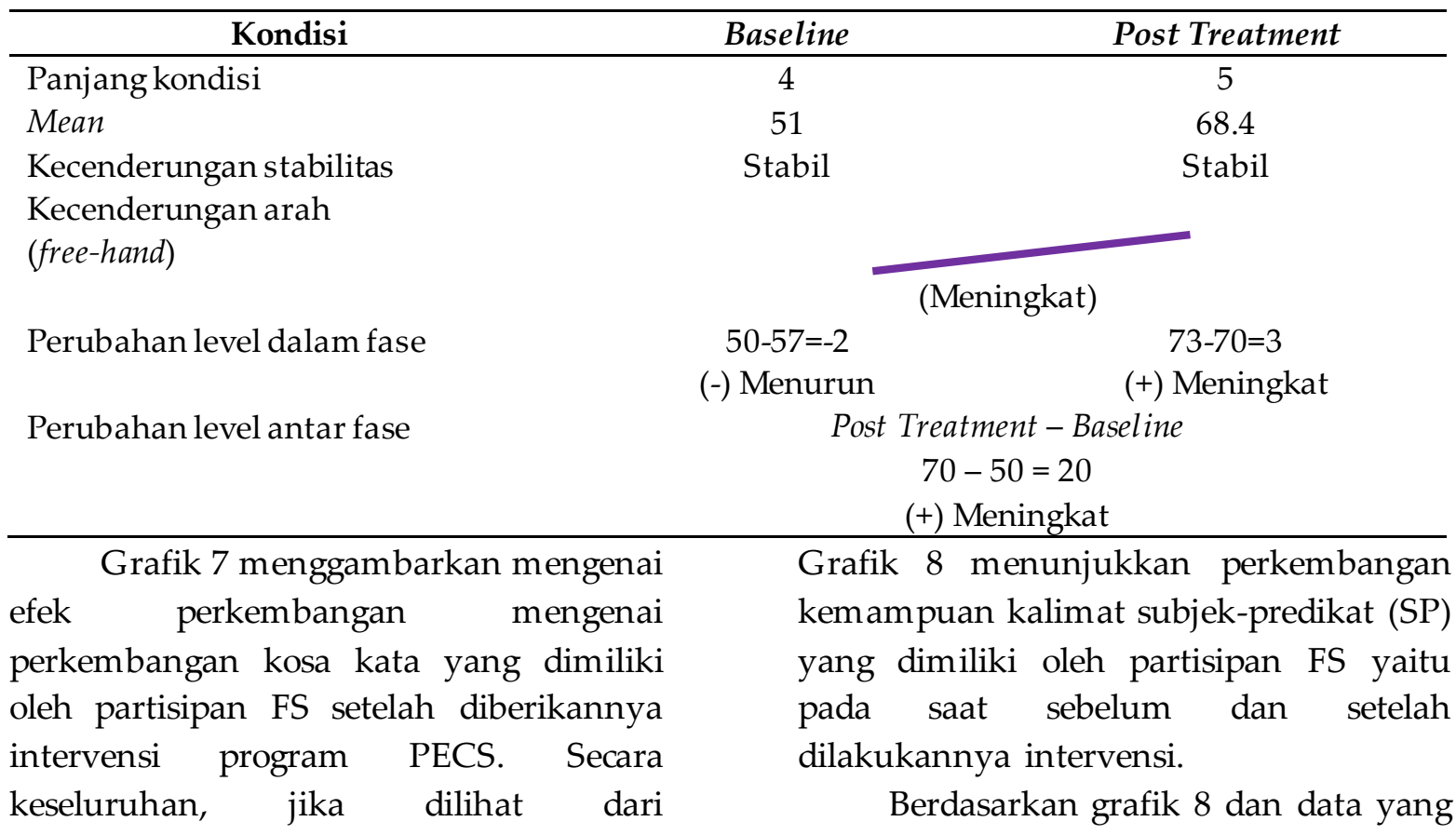

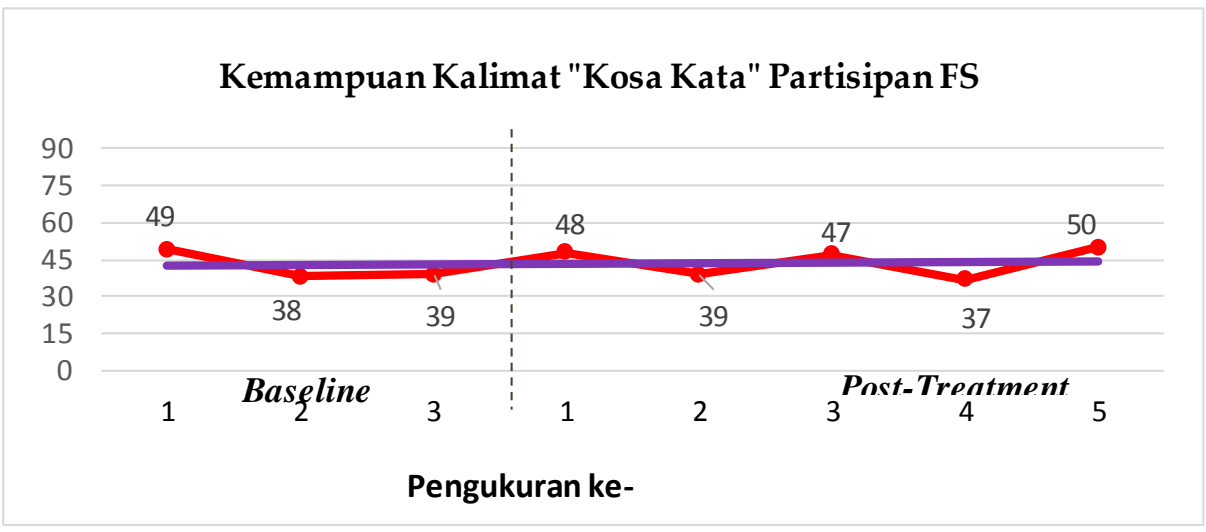

Grafik 7. Kemampuan kosa kata pada partisipan FS

kecenderungan arah (trendline) yang ada pada grafik 7 , maka arah garis peningkatan yang terjadi tidak begitu signifikan. Garis trend yang terjadi pada kedua kondisi (baseline dan post-treatment) cenderung terlihat konstan dan tidak begitu menunjukkan perubahan yang signifikan untuk kemampuan kosa kata partisipan FS. Namun demikian, jika dilihat dari perubahan level antar fase yang ada pada tabel 8 maka dapat dilihat jika terjadi peningkatan skor sebesar 9 poin antara fase baseline dan posttreatment, dimana kondisi post-treatment mendapatkan skor yang lebih tinggi dibandingkan pada saat kondisi baseline. ada di dalam tabel 9, diketahui jika kemampuan kalimat terstruktur dengan pola subjek-predikat (SP) pada partisipan FS mengalami peningkatan antara sebelum dan sesudah diberikannya intervensi. Hal ini nampak dari garis trendline (kecenderungan arah) yang menunjukkan kenaikan pada grafik di kondisi post-treatment. Selain itu, skor perubahan level antar fase juga menunjukkan adanya kenaikan sebesar 7 poin di mana fase post-treatment lebih tinggi dibandingkan pada kondisi baseline (sebelum diberikannya intervensi). Hal ini mengindikasikan jika program intervensi PECS penyusunan kalimat 
Tabel 8.

Analisis Visual Inspection Kemampuan Kosa Kata Partisipan FS

\begin{tabular}{lcc}
\hline \multicolumn{1}{c}{ Kondisi } & Baseline & Post-Treatment \\
\hline $\begin{array}{l}\text { Panjang kondisi } \\
\text { Mean }\end{array}$ & 4 & 5 \\
$\begin{array}{l}\text { Kecenderungan arah } \\
\text { (free-hand) }\end{array}$ & 42 & 44.2 \\
Perubahan level dalam fase & (cenderung konstan) \\
Perubahan level antar fase & $39-49=-10 \quad 50-48=2$ \\
& $\begin{array}{c}\text { (-) Menurun } \\
\text { Post Treatment }- \text { Baseline }\end{array}$ \\
& \multicolumn{2}{c}{ 48-39=9 } \\
& \multicolumn{2}{c}{$(+)$ Meningkat } \\
\hline
\end{tabular}

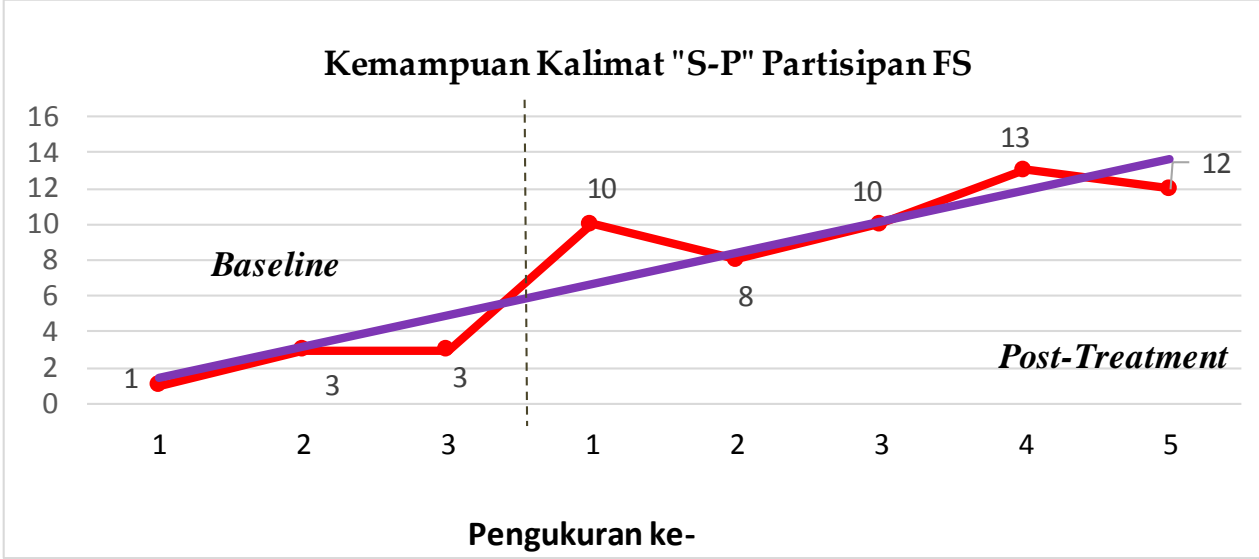

Grafik 8. Kemampuan kalimat subjek-predikat (SP) pada partisipan FS

diketahui dapat meningkat kemampuan

kalimat subjek-predikat (SP) pada partisipan FS.
Berdasarkan data pada grafik 9, dapat dilihat jika terjadi peningkatan kemampuan kalimat terstruktur pola

Tabel 9.

Analisis Visual Inspection Kemampuan Kalimat Subjek-Predikat (SP) pada Partisipan FS

\begin{tabular}{lcc}
\multicolumn{1}{c}{ Kondisi } & Baseline & Post Treatment \\
\hline Panjang kondisi & 4 & \multicolumn{2}{c}{5} \\
Mean & \multicolumn{2}{c}{6.8} \\
$\begin{array}{l}\text { Kecenderungan arah } \\
\text { (free-hand) }\end{array}$ & \multicolumn{2}{c}{ (Meningkat) } \\
Perubahan level dalam fase & $3-1=2$ 12-10=2
\end{tabular}

Perubahan level dalam fase

(-) Menurun

(+) Meningkat

Perubahan level antar fase

Post Treatment-Baseline

$$
10-3=7
$$

$(+)$ Meningkat

Grafik 9 menunjukkan perkembangan kemampuan kalimat predikat-objek (PO) yang dimiliki oleh partisipan FS yaitu pada saat sebelum dan setelah dilakukannya intervensi. predikat-objek (PO) pada partisipan FS. Hal ini terlihat dari kecenderungan arah yang diberikan oleh garis trendline yang mengalami kenaikan pada kondisi posttreatment (setelah diberikannya intervensi 


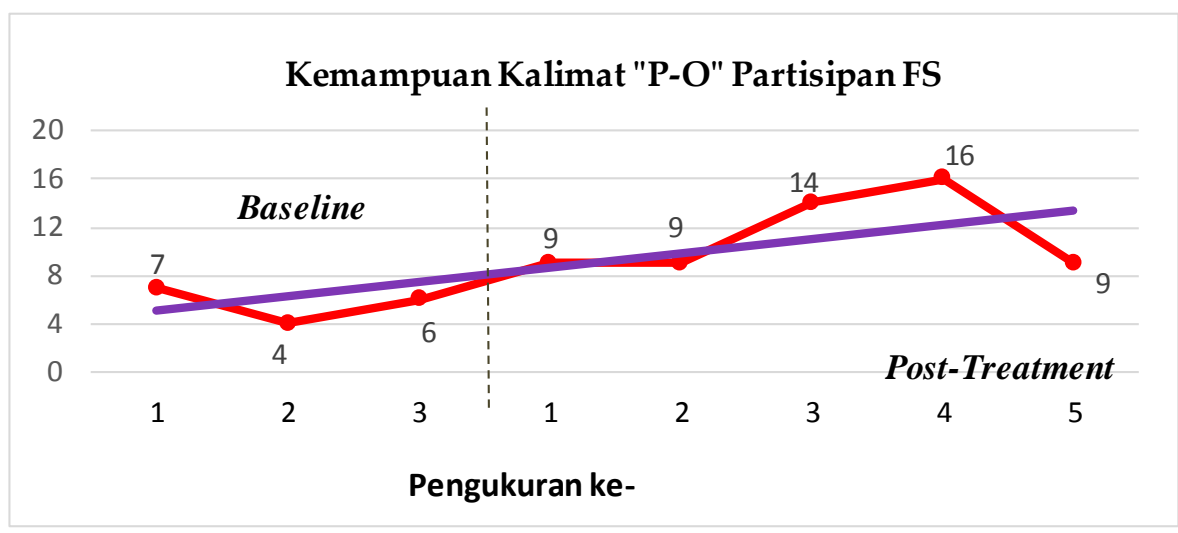

Grafik 9. Kemampuan kalimat subjek-predikat (SP) pada partisipan FS

Tabel 10.

Analisis Visual Inspection Kemampuan Kalimat Predikat-Objek (PO) pada Patisipan FS

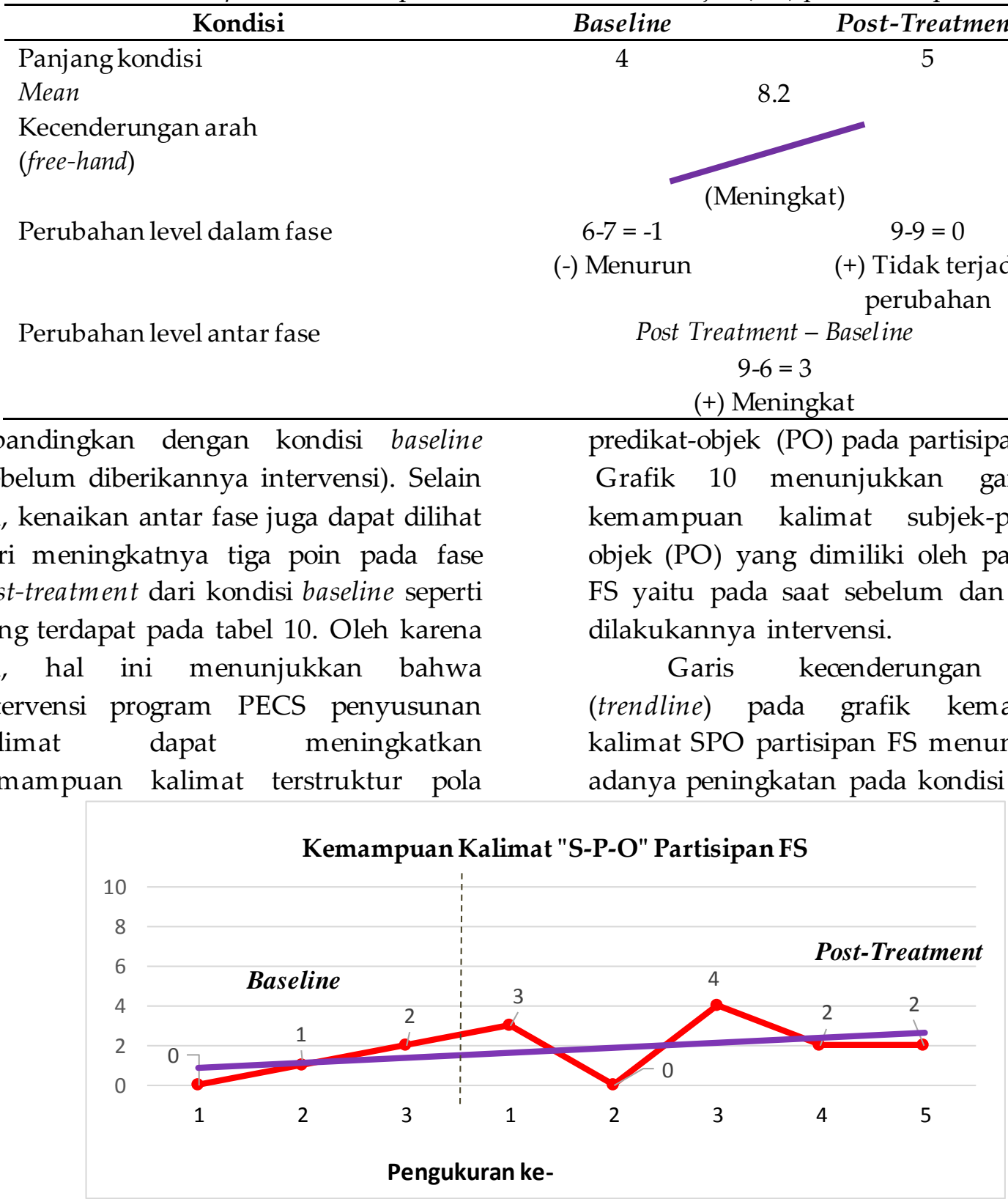

Grafik 10. Kemampuan kalimat subjek-predikat-objek (SPO) pada partisipan FS 
treatment jika dibandingkan dengan kondisi baseline sebelum diberikannya intervensi. Namun demikian, jika ditelisik lebih dalam peningkatan yang terjadi tidak terlalu signifikan, tidak hanya terletak pada perubahan garis trend namun juga pada perubahan 1 poin pada skor level antar fase sebagaimana dilihat pada tabel 11. Jika dibandingkan dengan efek terhadap kemampuan kalimat SP dan juga $\mathrm{PO}$, perkembangan dari kalimat SPO pada partisipan FS tergolong lebih rendah dibandingkan peningkatan yang terjadi pada kemampuan kalimat SP dan juga PO nya. prinsip visual support dapat mempermudah anak-anak autis dalam melatih kemampuan komunikasinya.

Kesulitan dalam komunikasi berbicara telah diketahui menjadi salah satu permasalahan utama yang dialami oleh individu dengan autis (APA, 2013). Sejalan dengan hal ini, Siegel (2003) juga pernah mengungkapkan bahwa sebagian besar anak autis menunjukkan perkembangan berbicara yang jauh lebih lambat dibandingkan anak seusianya. Kedua partisipan pada penelitian ini (FS dan GB) juga mengalami hal yang sama, meskipun pada faktanya keduanya sudah

Tabel 11.

Analisis Visual Inspection Kemampuan Kalimat Subjek-Predikat-Objek (PO) pada Partisipan FS

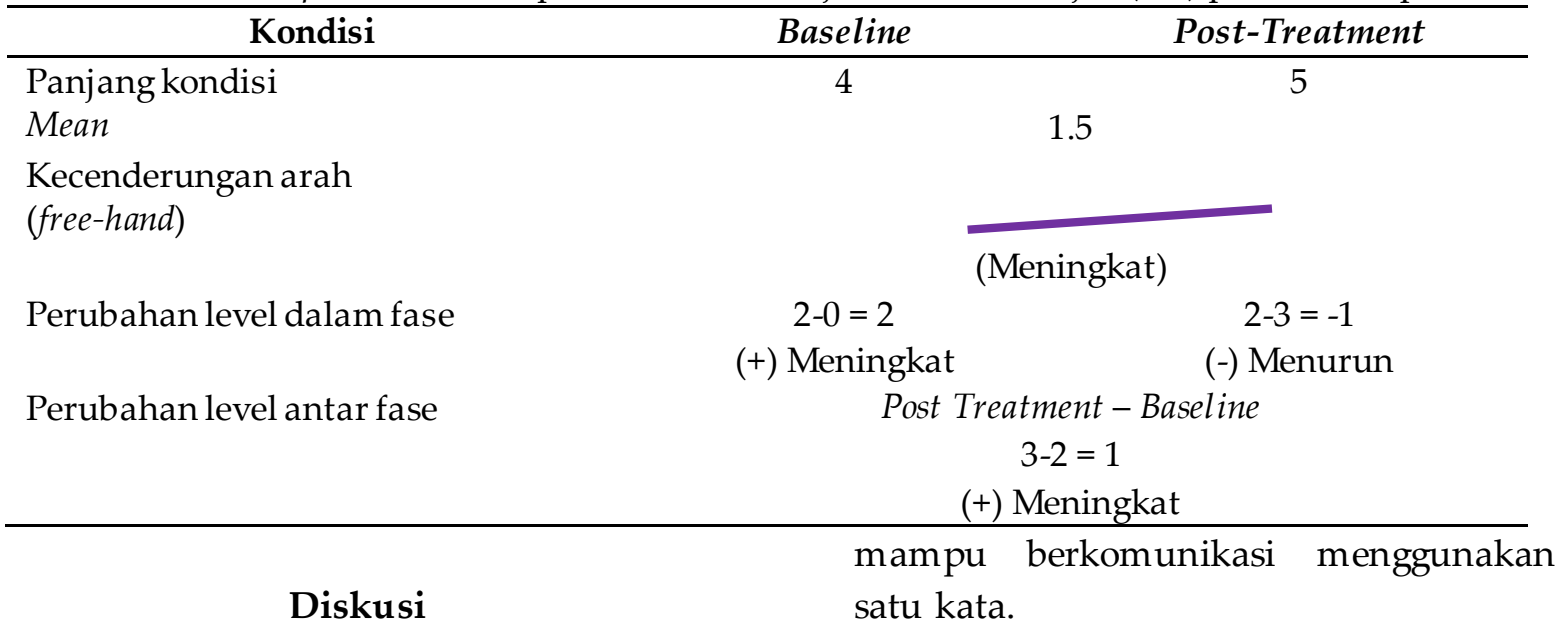

Tager-Flusberg et al. (2005)

Hasil penelitian menunjukkan bahwa adanya peningkatan kemampuan berbicara terstruktur pada kedua partisipan (FS dan GB) setelah diberikannya intervensi program PECS (picture exchange communications system). Hal ini terlihat dari perbandingan dua kondisi penelitian, yaitu pada saat kondisi baseline dan pada saat kondisi post-treatment. Kesimpulan hasil penelitian ini semakin menguatkan beberapa hasil studi penelitian sebelumnya. Salah satunya yang pernah dilakukan oleh Odluyurt, Aldemir dan Kapan (2016) yang melaporkan bahwa intervensi PECS yang menggunakan mengungkapkan bahwa permasalahan lain yang memang akan dialami oleh anak autis yang sudah memiliki kemampuan verbal satu kata adalah terkait dengan kaidah tata bahasa dalam bahasanya, atau hal ini biasa disebut dengan istilah sintaksis (Carol, 2004).

Salah satu aspek penting dari kemampuan berbicara yang mulai berkembang dan meningkat pada anak normal di usia 4-7 tahun adalah aspek sintaksisnya, yaitu mengenai kemampuan penyusunan kalimat (Carrol, 2004). Pada rentang usia ini, anak normal pada umumnya sudah mulai merangkai kalimat sederhana dengan 
baik dan berkembang menjadi semakin konsisten. Sebagian besar di antara mereka bahkan sudah mulai menggunakan kalimat tanya dan kalimat negatif dalam suatu pembicaraan. Kontras dengan hal ini, anak yang mengalami gangguan autisme justru memiliki kelemahan dalam kaidah gramatikal bahasanya saat terlibat dalam komunikasi pada lingkungan sosialnya. Hal ini juga yang dialami oleh kedua partisipan, GB dan FS. Kedua partisipan masih berada pada tahapan komunikasi berbicara satu kata yang disertai dengan beberapa permasalahan lain seperti seringkali terbalik dalam pola kalimat atau bahkan mengganti kata dengan dengung tidak berarti. Sejalan dengan ini, Tager-Flushberg et al. (2005) mengungkapkan bahwa anak autis akan cenderung menghilangkan morfem, dan mengisi kalimatnya dengan babbling atau bahkan menggunakan penempatan kata yang tidak tepat pada pembicaraan dalam interaksi sosialnya (Parritz dan Troy, 2011).

Program PECS (picture exchange communication system) yang dilakukan pada penelitian ini menggunakan visual support, yaitu penerapan program melalui kartu-kartu bergambar. Hal ini bertujuan untuk memudahkan partisipan autis dalam memahami konsep kalimat terstruktur melalui media visual. Seperti yang diungkapkan oleh Grandin (1996) bahwa sebagian besar individu autis cenderung lebih menganggap asing informasi yang bersifat verbal. Hal ini dikarenakan mereka cenderung lebih bergantung pada kemampuan visual dalam fungsi kinerja otaknya dibandingkan pada kemampuan verbalnya untuk menerjemahkan sesuatu yang bersifat abstrak menjadi lebih konkret (Ring, 1999).

Hasil pada penelitian ini tidak hanya mengungkap kemampuan berbicara terstruktur secara umum dari kedua partisipan saja, namun juga mengungkapkan secara spesifik terkait kemampuan berbicara terstruktur dengan pola dua kata (SubjekPredikat/Predikat-Objek) dan juga pola kalimat tiga kata (Subjek-PredikatObjek). Pada kondisi ini, kedua partisipan (FS dan GB) diketahui mengalami peningkatan pada kemampuan berbicara dengan pola dua kata yaitu SP (subjekpredikat) dan juga PO (predikat-objek). Namun demikian, pada kemampuan berbicara pola tiga kata yaitu SPO (subjek-predikat-objek), hasil analisis menunjukkan jika tidak terjadinya peningkatan pada kedua partisipan. Kondisi kedua partisipan pada saat sebelum dan setelah intervensi cenderung konstan. Hal ini dapat disimpulkan bahwa rentang waktu yang dijalankan oleh program PECS ini secara spesifik hanya dapat meningkatkan kemampuan kalimat terstruktur dua kata (SP/PO), namun untuk kalimat dengan pola tiga kata (SPO) memerlukan rentang waktu yang lebih panjang.

\section{Kesimpulan}

Berdasarkan hasil penelitian yang telah dilakukan, dapat disimpulkan bahwa program PECS (picture exchange communication system) dapat meningkatkan kemampuan berbicara terstruktur pada anak autis. Peningkatan kemampuan berbicara terstruktur pada partisipan tersebut terkait dengan diberikannya beberapa stimulasi dengan menggunakan konsep visual yang melibatkan kartu bergambar yang memiliki kedekatan pada kehidupan sehari-harinya.

\section{Saran}

Peneliti selanjutnya diharapkan dapat memperhatikan kondisi mood yang 
dialami oleh partisipan yaitu dengan cara memberikan variasi terhadap pelaksanaan trial yang berulang untuk menghindari kejenuhan atau perasaan bosan pada partisipan. Pengukuran terhadap kebertahanan perubahan perilaku (follow up) untuk mengetahui seberapa lama efek program intervensi bertahan pada partisipan juga perlu dilakukan.

Pihak guru diharapkan dapat terus melanjutkan penggunaan program PECS penyusunan kalimat ini sehingga diharapkan efek yang akan di dapatkan oleh partisipan bersifat jangka panjang. Bagi orangtua, diharapkan dapat menyediakan waktu lebih banyak di rumah untuk mendampingi partisipan dalam menstimulasi kemampuan berbicara terstrukturnya dengan menggunakan program PECS secara kontinyu agar adanya keseimbangan perlakuan antara di rumah dan di sekolah sehingga mampu memperkuat efek dari program intervensi.

\section{Kepustakaan}

American Psychiatric Association. (2013). Diagnostic and statistical manual of mental disorders (Edisi kelima). Washington, DC: Author.

Bartolucci, G., Pierce, S. J., \& Streiner, D. L. (1980). Cross-sectional studies of grammatical morphemes in autistic and mentally retarded children. Journal of Autism and Developmental Disorders, 10(1), 3950. doi: $10.1007 / \mathrm{BF} 02408431$

Bondy, A. S., \& Frost L. A. (1994). The picture exchange communication system. Focus on Autistic Behavior, 9(3), 1-19. doi: $\underline{10.1177 \% 2 F 10}$ $\underline{8835769400900301}$

Carrol, D. (2004). Psychology of language. Universitas Michigan: Thomson and Wadsworth

Frith, U. (2003). Autism: explaining the enigma (Edisi kedua). New York: Oxford University Press.

Grandin, T. (1996). My experiences with visual thinking sensory problems and communication difficulties. United States: Center for the Study of Autism.

Kazdin, A. E. (2011). Single-case research designs: Methods for clinical and applied settings (Edisi kedua). New York, NY: Oxford University Press.

Kerig, P., Ludlow, A., \& Wenar, C. (2012). Developmental psychopathology: From infancy through adolescence (Edisi keenam). New York, NY: MoGrawHill Education.

Labola, Y. A. (2017). Data anak autisme belum akurat? Diunduh dari https://www.kompasiana.com/yos0 8/58eb4717af7a61ec1378f3e7/anakautisme?page $=$ all

Odluyurt, S., Aldemir, O., Kapan., A. (2016). An investigation on the effects of PECS and observational learning in initiating and maintenance of communication among children with autism. International Journal of Early Childhood Special Education, 8, 151164. doi: 10.20489 /intjecse. 284658

Parritz, H. \& Troy, F. M. (2011). Disorders of childhood: Development $\mathcal{E}$ psychopathology. USA: Wadsworth Cengage Learning.

Ring, H., Cohen, B., Wheelwright, S. (1999). Cerebral correlates of preserved cognitive skills in autism: a functional MRI study of embedded figures task performance. United States: National Institues of Health.

Santrock, J. W. (2010). Child development (Edisi kedua belas). Singapore: MoGraw-Hill.

Shaughnessy, J., Zechmeister, B., \& Zechmeister, S. (2009). Research 
methods in psychology. New York: Mc Graw-Hill.

Siegel, B. (2003). Helping children with autism learn. New York: Oxford University Press.

Tager-Flushberg, Paul, \& Lord. (2005). Handbook of autism and pervasive developmental disorders vol 1. New York: John Wiley \& Sons.
Thunberg, G. (2013). Early communication interention for children with autism spectrum disorder. Advances in Autism Spectrum Disorder, 1, 719-746. doi: $\underline{10.5772 / 54881}$ 